\title{
Correction to: The changing landscape of dermatology practice: melanoma and pump-probe laser microscopy
}

Charles J. Puza ${ }^{1}$ - Warren S. Warren ${ }^{2} \cdot$ Paul J. Mosca ${ }^{3}$

Published online: 5 October 2017

(C) Springer-Verlag London Ltd. 2017

Erratum to: Lasers Med Sci

https://doi.org/10.1007/s10103-017-2319-2

The published online version contains mistake. Warren S. Warren was not included in the author group section. Corrected author group section is shown above.

The online version of the original article can be found at https://oi.org/ 10.1007/s10103-017-2319-2

\footnotetext{
Charles J. Puza

Charles.puza@duke.edu

Paul J. Mosca

Paul.mosca@duke.edu

1 Duke University School of Medicine, Durham, NC, USA

2 Duke University, Department of Chemistry, Durham, NC, USA

3 Duke University, Department of Surgery, Durham, NC, USA
} 